\title{
The Use of Politeness Strategies in the Indonesia's 2019 Presidential Campaign Teams on Online News Media
}

\author{
Bismo Prasetyo $^{1}$, Rustono ${ }^{2}$, R. Pristiwati ${ }^{3}$ \\ \{ $\left.\underline{\text { bismo.prasetyo159@gmail.com }}^{1}, \underline{\text { rustono@mail.unnes.ac.id }}^{2}, \underline{\text { rahayupristiwati@yahoo.co.id }}^{3}\right\}$ \\ Master Program of Indonesian Language Education Studies, Graduate School, Universitas Negeri \\ Semarang, Indonesia ${ }^{1,2,3}$
}

\begin{abstract}
The politeness strategy can be found in daily conversations and in debating events. One of the debates of concern for this study is the debate between two presidential election campaign teams in Indonesia. This article sought to describe the strategies used by both groups on online news media and to find out whether there is any significant difference between in the use of positive and negative politeness strategies. This research used descriptive qualitative methods to analyze sixteen articles of media coverage of news with high political salience from two important national online news media having opposite ideology, MediaIndonesia.com and Kompas.com. Discussion primarily draws upon Brown and Levinson's politeness theory. The result of the research shows that each groups of election campaign team used various politeness strategies projected by three context-driven politeness strategies. This implies that each teams should consider politeness attracts positive attention, gives tough situations a chance to turn around.
\end{abstract}

Keywords: politeness strategies, 2019 Indonesian presidential election, online media, pragmatic competence.

\section{Introduction}

The culture of everyday life includes the whole complex of human relations: the culture of communication and behavior, the culture of mass media communication and the culture of lifestyles. In linguistic terms, the considered category of everyday life presents a dynamic system of the whole amount processes of language functioning, all forms and possible types of social communication, typically manifested in specific kinds of individual or collective discourses [1]. The text in the mass media is a lingual phenomenon. In its form as text, the news is not just a lingual structure phenomenon, but also as a mind building (cognitive structure) as well as action building (action structure) [2]. The Internet has transformed access to the news with most citizens in Indonesia democracies having access at the news can be readily accessed through a single push of a button on a handheld device. Regarding this, Boulianne [3] stated that online news has the strongest effect on engagement, compared with other uses of the Internet.

In journalism, when many news organizations are avidly building their online presence and some are indeed taking a 'digital first' strategy, curated information has also garnered much attention [4]. One of the news media function in a democracy is the reporting of politics 
and institutions. Traditionally, political discourse has occurred primarily via face-to-face interactions, but today online interactions represent a substantial portion of political activity.

As an evolving pattern of political discourse, it becomes noteworthy to account for the conversation engagements of participants to properly address the discursive and pragmatic strategies of language indexing it. Furthermore, Pristiwati et al. [5] stated that political discourse maintains a significant role to deliver information towards society as a medium of communication. This role is really intense by the existence of various information needed by a democratic society.

Observation made by Moglie and Turati [6] in understanding whether the media's coverage of political relevant news affect voters' opinions when the election gets closer. In particular, they study how the politically relevant news by media outlets can be bias. The result of their study shows that both news media while covering the same news, have slightly differed way to produce an article about corruption which varies according to the regional electoral cycles, the newspaper's ideology, and their interaction. The general strategy adopted by both is to publish more articles related to politicians of opposing ideology while reducing those about general episodes of corruption. However, their journalism research has mainly directed at group level contacts, i.e. at the interaction between reporters and officials collectively. Individual contacts and politeness strategies have not received that much attention.

Accordingly, the present study highlights the pragmatic analysis of the following questions: (1) what are the politeness strategies used by each group of 2019 presidential campaign teams on online news media? (2) How is the significant difference in the use of positive and negative politeness strategies between the groups of electional campaign teams?

This study is a unique contribution to the academic literature because it focuses on how online news media may subtly transform engagement in civic and political life. A number of studies have bridged a gap between a new dimension of a political campaign with the introduction of media debates into the election campaign system (Akinwotu, 2015 [7]; Burhanuddin \& Sumarlam, 2015 [8]; Clementson, 2018 [9]; Sifianou, 2019[10]). Furthermore, Ameedi \& Khudier [11] stated that the new media can be regarded as a powerful instrument used by politicians to attract the audience's attention to a specific political action. Politicians deploy a great number of linguistic strategies and rhetorical devices in their political propaganda discourse in order to mobilize their political actions and to influence public opinions.

As for news media, we focus primarily on two of the most important Indonesian online news, MediaIndonesia.com and Kompas.com. Our findings suggest that MediaIndonesia.com produces more articles about corruption scandals involving opposition presidential candidates in the weeks before the elections. On the contrary, Kompas.com increases the number of articles to reduce the number of those about episodes of corruption without any political connection for the opposition. This difference in the behavior of the two newspapers is likely driven by the relative importance of profits and ideology as well as the political involvement of its ownership. This paper will try to analyze the general strategy adopted by both groups of each presidential campaign teams used various politeness strategies on both online media. 


\section{Method}

This study examines the notion of face and politeness aspects of two Indonesia presidential election campaign teams on Online News. This research employs the pragmatic approach and a descriptive qualitative approach which is done by collecting the data in the form of utterances, classifying the data, analyzing the data chronologically by page on which they are written, and then drawing the conclusion of the use of positive and negative politeness strategies used by 2019 presidential election campaign teams in Indonesia on online news media, based on Brown and Levinson's politeness theory (1987). The data of the research were five articles collected from each online news media with high political salience, namely MediaIndonesia.com and Kompas.com from Feb 10 - March 152019.

Data collection is done by document analysis and through observing methods consisting of free conversational and note methods. A set of laptop, a mobile phone were used in this study. Then each news article from MediaIndonesia.com and Kompas.com were to be read several times and transcripted in order to achieve the aim. After that the transcription of the dialogues containing postive or negative politeness strategy from the articles was used to explore various types of context-based strategy used by each electional campaign teams.

Data analysis techniques using interactive analysis techniques consisting of data reduction, data display, and conclusion.

\section{Result and Discussion}

This section examines the politeness strategies identified in the data and their pragmatic import. The data is characterised by politically-driven issues utterances which include governance, economic and social development, all situated in political and media events. Three politeness strategies are significant in the data, namely, persuasive, offensive and defensive politeness strategies.

\subsection{Persuasive Politeness Strategy}

Polite verbal behaviour in this context means behaving in a way that is socially correct by showing understanding of situation, giving due regard to, and care (solidarity) for the feelings of others. Two types of persuasive strategies are significant in our data: namely; promising and testimonial argument. Usually, candidates employ promising and testimonial argument to maintain a positive face or achieve face saving acts (positive politeness). It is observed that while all the candidates engage the strategy of promising. It is observed that while all the supporters engage the strategy of promising, the $T K N$ (incumbent team) also employ the testimonial argument. The following are a few examples:

Example 1: TKN spokesman (incumbent team) Ace Hasan

"Mr. Jokowi's statement was a motivation for the volunteers to more socialize the 01 pair in the community. The volunteers must work to convey the achievements and various programs offered to the people. Especially new programs such as Cheap Food Package cards, Smart Indonesian cards and Pre-Work Card."

Example 2: $T K N$ spokesman (incumbent team) Ace Hasan

"The Jokowi-Kiai Ma'ruf government will continue to revitalize the mental revolution. Changes in the mental character of the nation from a negative mental character to a positive mental character must be a human and cultural development strategy that is 
constantly internalized in the development system so that it becomes systemic and undergoes civilization in daily behavior."

The supporters in the examples above employ positive politeness strategies of promising and testimonial argument to maintain their good image as well as the image of their parties. Since their main intention is to persuade the electorate, their utterances are therefore politic or appropriate given the context of the data as a campaign text. The extracts above are part of the candidates' responses by engaging in promising, supporters in the data are able to influence the electorate and hoodwink them into taking decisions that are beneficial to the contestants They engage in promising by deploying phrases with futuristic semantic implications using the modal auxiliary verbs will and would such as, 'we would address...', 'we will continue...', 'The volunteers must work to convey the achievements...', etc (see the italicised portions in the extracts). Sometimes, politicians maintain their positive face (face-saving act) by making sweeping statements intended to hoodwink the electorate into accepting their offer.

\subsection{Offensive Politeness Strategy}

Supporters in media political debate may also engage one another in offensive verbal attacks. Offensive verbal attack is a negative (impolite) politeness strategy and it constitutes a threat (FTA) to the face of an opponent. offensive politeness strategy is defined as a verbal attack; usually an onslaught or a fierce assault or aggression, intended either to cause disaffection and labelled as unfit for the presidency position. The following are few examples: Example 3: BPN spokesman (opposition supporter) Ferdinand Hutahean

"In my opinion, paying unemployment is very unreasonable. It is beyond the limits of reasoning to see from the structure of our state budget so far, which is heavy. In order to pay honorariums alone, our state budget just collides, often late. Now how much unemployment do you want to pay? If the salary is the same, then the honorariums can just stop. Of course, Rp. 200 thousand will cause injustice, because the working contractor is desperately paid Rp. 300 thousand, the difference is only Rp. 100,000.”

Example 4: BPN spokesman (Opposition supporter) Ferdinand Hutahean

"Jokowi once again promised a program of Cheap Food Packages and Indonesian Student Cards to the tertiary level. The question now, what about the BPJS card? Now people have difficulty getting treatment. That was just taken care of before talking to another card. The distribution of these cards is an attempt to divert public attention from the failure of Jokowi's campaign on infrastructure that does not make people willing and easy to vote for him to become president."

Example 5: BPN spokesman (Opposition supporter) Ferdinand Hutahean

"The distribution of cards is an attempt to divert public attention from the failure of Jokowi's campaign. About infrastructure that does not go away makes the people willingly and easily choose him again to become president. The distribution of these cards is not clear where the source of the budget is"

The supporters in the examples above employ negative politeness strategies to threaten their opponent's candidate image. Through the technique of framing and blackmailing, the speaker, in a rather sarcastic manner, implicitly categorises Jokowi as inept, incompetent and lacking in the capacity to rule the country. Thus, he constructs the referent as inept, lacking the capacity to coordinate the resources of the state to uplift the standard of living of the citizens. 


\subsection{Defensive Politeness Strategy}

Another form of impolite verbal behaviour found in the data is defensive politeness strategy. This is usually employed by a supporter to counter any offensive onslaught that threatens his or her face. A supporter whose face has been threatened may react either by clarifying issues, refuting allegations levelled against him (rebuttal) or through a counter attack (FTA bald-on-record) on the opponent who made the allegation. Such a contestant may become aggressive, confrontational or even rude in a bid to defend or save his face. Instances of these in the data are presented below with analysis.

Example 6: $T K N$ spokesman (incumbent supporter) Ace Hasan

"And of course if for example voters feel that all this time they have been fed with information, we do clarification, it is done systematically by us. Volunteers from the community and political parties seriously campaigned door-to-door, and ensured that Mr. Jokowi campaigned for positive things."

Example 6 is the response of the accusation of the $B P N$ team, that Jokowi has not harnessed the potentials of the state; especially on the oil sector and that he abandoned the infrastructure initiated by the immediate past PDP administration (example $4 \& 5$ )

Example 7: $B P N$ spokesman (Opposition supporter) Ferry Mursyidan

"After we check, we don't know Kornas. Yes, people can declare Prabowo-Sandi volunteers, in the context of the Directorate of BPN Volunteers, I think there are four headquarters that all volunteers can attend there, Aspiration Houses in Cut Meutia, National Secretariat at HOS Cokro, Djoeang House in Wijaya, and M16 in Melawai. They are volunteers but have not been confirmed by us. And they claimed, when I knew there was a case, they were not right."

The $B P N$ team in example 7 simply engages in a face saving act by refuting the allegation of hoax perpetrator levelled against Prabowo-Sandi's sympathizer. He denied the volunteers that they were not registered within BPN volunteers.

\section{Conclusion}

This study has examined the discursive and pragmatic strategies of language use are the politeness strategies deployed by each group of Indonesia's 2019 presidential campaign teams in the management of their face and that of their opponents on online media. The analysis has revealed that the data is characterised by politically-driven issues which include governance, economic and social development, all situated in political and media events. Two types of verbal behaviour namely polite and impolite verbal behaviour which are projected by three context-driven politeness strategies namely persuasive, offensive and defensive politeness strategies marked contestants' utterances. While persuasive politeness strategy, which is exemplified by promising and testimonial argument, projects polite verbal behaviour; offensive and defensive politeness strategies employed by contestants to categorise and construct one another as corrupt, inept, incompetent, unfit, dishonest, deceitful, project impolite verbal behaviour. 


\section{References}

[1] M. Ryabova. "Politeness Strategy in Everyday Communication". Procedia - Social and Behavioral Sciences (206), 90-95, November 11 2015. [Online]. Available: Science Direct, http://www.sciencedirect.com. [Accessed October 19, 2018].

[2] T. Yuniawan.. "Ecolinguistic Study of Conservation News Texts". International Journal of Humanity Studies, 1 (2), 163-183, March 2018. [Online]. Available: Sanata Dharma University, http://e-journal.usd.ac.id/index.php/IJHS. [Accessed January 9, 2019].

[3] S. Boulianne. "Online News, Civic Awareness, and Engagement in Civic and Political Life". New Media \& Society, 1-17, Dec 19 2015. [Online]. Available: SAGE Publications inc., https://nms.sagepub.com. [Accessed October 11, 2018].

[4] X. Cui and Y. Liu. "How Does Online News Curate Linked Sources? A Content Analysis of Three Online News Media". Journalism, 1-19. August 92016.

[5] R. Pristiwati, Rustono, F. Rokhman, and H. B. Mardikantoro. (2016). "Metaphorical Meanings Inside of Discourse of President, Parliament, And Major National Election 2014". The Journal of Educational Development, 4 (2), 167-174, Nov 20 2016. [Online]. Available: Unnes Journals, http://journal.unnes.ac.id/sju/index.php/jed. [Accessed January 4, 2019].

[6] Moglie, M. L., \& Turati, G. (2019). "Electoral Cycle Bias in the Media Coverage of Corruption News". Journal of Economic Behavior and Organization, 163, 140-157, May 5 2019.

[7] S. A. Akinwotu. "Vision for Sustainable Development: Pragmatic Strategies of Media Political”. International Journal of Language and Literature, 3 (2), 134-143, Dec 2015.

[8] Burhanuddin, \& Sumarlam. "Strategi Kesopanan Berbahasa Presiden Joko Widodo: Potret Tindak Tutur Penanganan Masalah Sosial-Politik Bangsa”. Adabiyyāt, 14 (2), 167-190, Dec 2015.

[9] D. E. Clementson. "Deceptively Dodging Questions: A Theoretical Note on Issues of Perception and Detection". Discourse \& Communication, 00 (0), 1-19, 2018. [Online]. Available: SAGE Publications inc., https:// journals.sagepub.com/home/dcm. [Accessed October 14, 2018].

[10] M. Sifianou. "Im/politeness and In/civility: A Neglected Relationship?". Journal of Pragmatics, 147, 49-64, May 82019.

[11] R. T. Ameedi and Z. A. Khudhier. "A Pragmatic Study of Barak Obama's Political Propaganda". Journal of Education and Practice, 6 (20), 75-86, 2015. [Online]. Available: International Knowledge Sharing Platform, https://files.eric.ed.gov/fulltext/EJ1079046.pdf. [Accessed October 11, 2018]. 